\title{
Dhenggung Asmarandana dan Dhegung Banten: Sebuah Komparasi
}

\author{
Teguh $^{1}$ \\ Jurusan Karawitan, Fakultas Seni Pertunjukan, Institut Seni Indonesia Yogyakarta
}

\begin{abstract}
The Comparation of Dhenggung Asmarandana and Dhegung Banten. Penelitian ini membahas perbandingan antara gending Dhenggung Asmaradana gaya Surakarta dengan gending Dhegung Banten gaya Yogyakarta. Berdasarkan penelitian dapat disimpulkan bahwa kedua gending memiliki persamaan dan perbedaan. Persamaan keduanya terletak pada laras, pathet, bentuk gendhing, struktur gendhing, serta balungan gending. Sedangkan perbedaannya hanya pada nama dan garap tabuhan bonang.
\end{abstract}

Key words: Gendhing bonang, soran, gamelan peace.

\section{Pendahuluan}

Perjanjian Giyanti tahun 1955 yang dikenal dengan peristiwa paliyan nagari membagi kerajaan menjadi dua yaitu Kasunanan Surakarta dan Kasultanan Yogyakarta. Masing-masing kerajaan berusaha menemukan jati dirinya yang khas. Raja sebagai penguasa adalah pusat segalanya, termasuk kehidupan kesenian yang merupakan salah satu penegak kewibawaan raja.

Keraton Kasunanan Surakarta dan Kasultanan Yogyakarta selain sebagai pusat pemerintahan, keduanya berkembang pula sebagai pusat kebudayaan yang selanjutnya menjadi panutan bagi daerah yang menjadi kekuasaanya. Pada akhirnya kedua keraton Jawa ini mampu menciptakan dua tradisi besar yaitu tradisi Surakarta dan Yogyakarta. Menurut Edi Sedyawati (1981: 27) kedua tradisi itu tampak selalu bersaing terutama pada produk seninya, baik seni busana, tari, pedalangan maupun karawitannya. Hal ini sangat wajar karena baik tari, pedalangan maupun karawitannya sematamata bukan merupakan kesenian untuk hiburan belaka melainkan merupakan salah satu unsur kewibawaan Raja.

Tradisi Surakarta dan Yogyakarta merupakan tradisi yang unik karena keduanya kelihatan sama. Hal ini karena keduanya berakar dari budaya yang sama yaitu Mataram (Soedarsono: t.t., 78). Namun yang kelihatannya sama itu sebenarnya banyak terdapat perbedaan karena keduanya telah menemukan jati dirinya. Dengan kata lain, kedua tradisi ini merupakan tradisi serupa tapi tak sama.

Adanya perbedaan tradisi gaya Yogyakarta dan Surakarta, menginspirasi penulis untuk menguraikan berbagai fenomena yang sangat menarik ini. Beberapa penulis telah melakukan penelitian terdahulu di antaranya: (1) Siswadi pada tahuyn 2000 dalam laporan penelitiannya berjudul "Penyajian Gendhing Bedhayan Yogyakarta dan Surakarta: Sebuah Komparasi." Gendhing bedhayan adalah gendhing yang dipakai untuk iringan tari bedaya dan srimpi; (2) Utami Ciptaningsih pada tahun 2003 melakukan penelitian yang berjudul "Penyajian Ladrang Rambu dan Rangkung Sekaten Yogyakarta dan Surakarta." Kedua gending ini termasuk gendhing wajib yang harus dibunyikan pada acara sekaten. Untuk melengkapi tulisan yang terdahulu, penulis mengkomparasikan salah satu gendhing sajian karawitan mandiri atau yang lazim disebut klenengan (Surakarta) atau uyon-uyon (Yogyakarta) yaitu gending Dhegunggung Asmarandana dan Dhegung Banten.

Meskipun nama gending di atas berbeda, namun dari perbedaan nama itu sesungguhnya nampak persamaan terutama dalam hal balungan, bentuk gendhing, laras, dan pathetnya. Materi pokok yang akan dibahas dalam tulisan ini meliputi laras, pathet, struktur, bentuk dan balungan gendhing. Maka, tujuan dari penulisan ini untuk mengetahui sejauh mana persamaan dan perbedaan kedua gending tersebut, dan dalam hal apa saja terjadi persamaan dan perbedaannya.

1 Alamat Korespondensi: Prodi Karawitan Fakultas Seni Pertunjukan ISI Yogyakarta, jalan Parangtritis KM 6,5 Sewon, Yogyakarta 55001. HP. 081804427860, Email: teguh@isi.ac.id. 


\section{Pembahasan}

\section{A. Dhenggung Asmarandana}

Buku Wedhapradangga (Prajapangrawit, 1990: 106) telah menyebut bahwa Gendhing Dhenggung Asmarandana, Dhenggung Gong, Dhenggung Sulur Kangkung, Dhenggung Mloyo, Dhenggung Laras, Dhenggung Turulare dan Dhenggung Banten dicipta pada masa pemerintahan Pakoe Boewono IV (1788 1820). Gendhing Dhenggung Banten, gendhing kethuk 4 kerep minggah 8 laras pelog pathet lima, sekalipun gendhing ini telah disebut dalam buku Wedhapradangga, tetapi para pengrawit sepuh yang ada di Surakarta dan para pengrawit pada umumnya tidak pernah mengetahui apalagi menabuh gendhing Dhenggung Banten. Itu artinya di Surakarta tidak pernah ada gendhing Dhenggung Banten.

Pernyataan para pengrawit di atas barangkali benar adanya, karena buku berjudul Balungan Gendhing Gaya Surakarta tulisan S. Mlayawidada (1977:9-11) hanya memuat enam balungan Gendhing Dhenggung. Tanpa Gendhing Dhenggung Banten, enam gendhing yang dimaksud adalah Dhenggung Sulur Kangkung, Dhenggung Mloyo, Dhenggung Asmarandana, Dhenggung Gong, Dhenggung Laras dan Dhenggung Turulare. Perlu diketahui bahwa buku Balungan Gendhing susunan S. Mlayawidada adalah satu-satunya buku balungan gendhing gaya Surakarta yang dipergunakan oleh para pengrawit, tidak saja di Surakarta melainkan di berbagai negara yang telah memiliki gamelan.

Gendhing-gendhing Karawitan Gaya Surakarta yang ada selama ini bersumber dari Keraton Kasunanan, Kepatihan, Mangkunegaran dan Prabuwinatan. Dari ke empat sumber itu gendhing yang sangat rinci kapan diciptakan adalah gendhing-gendhing dari keraton Kasunanan dan Mangkunegaran, salah satunya adalah gendhing Dhenggung Asmaradana.

Hal yang menarik meskipun Gendhing Dhenggung Banten telah disebut dalam buku Wedhapradangga tetapi kenyataanya di Surakarta tidak ada balungan Gendhing tersebut. Pada karawitan gaya Yogyakarta ditemukan gendhing Dhegung Banten tetapi di Yogyakarta bukan gendhing Dhenggung Banten melainkan gendhing Dhegung Banten. Perbedaan keduanya terletak pada nama dan balungan gendhingnya.
Menurut Supanggah (1988: 10), gendhinggendhing karawitan Gaya Surakarta pada dasarnya dikelompokkan menjadi tiga yaitu Gendhing Rebab, Gendhing Gender, Gendhing Bonang. Gendhing Bonang adalah gendhing yang dalam penyajiannya tidak melibatkan ricikan garap seperti rebab, gender barung, gender penerus, gambang, siter, suling dan vokal (pesindhen dan gerong). Gendhing Dhenggung Asmarandana termasuk jenis gendhing bonang berbentuk kethuk 4 kerep minggah 8 berlaras pelog dan berpathet lima. Gendhing-gendhing bonang yang berlaras pelog pathet lima umumnya dibunyikan untuk mengawali sajian klenengan pada malam hari, biasanya laras pelog pathet lima disisibi Gendhing Bonang laras slendro pathet nem. Sebagai contoh, setelah menyajikan gendhing bonang Dhenggung Asmaradana Gendhing Kethuk 4 Kerep Minggah 8 laras pelog pathet lima maka gendhing bonang yang berlaras slendro dipilih gendhing Sidamukti, Gendhing Kethuk 4 Kerep Minggah 8 Laras Slendro Pathet Nem. Tradisi selama ini yang berlaku jika klenengan pada siang hari maka gendhing bonang yang dipilih selalu laras pelog pathet barang dan disisibi gendhing bonang laras slendro pathet manyura. Oleh karena itu tradisi karawitan gaya Surakarta gendhing-gendhing yang berlaras Slendro Pathet Sanga dan Gendhinggendhing yang berlaras Pelog Pathet Nem tidak memiliki gendhing bonang. Bentuk gendhing bonang yang paling kecil adalah Gendhing Kethuk 2 Kerep Minggah 4, baik laras slendro maupun laras pelog.

Dalam tradisi karawitan Surakarta, bentukbentuk gendhing dikelompokkan menjadi tiga yaitu (1) Bentuk Gendhing Ageng yang berukuran kethuk 4 kerep, kethuk 4 arang dan kethuk 8 kerep; (2) Gendhing Tengahan atau sedheng yaitu gendhing-gendhing kethuk 2 kerep dan; (3) Gendhing Alit berukuran ladrang, ketawang, dan sebagainya (Martopangrawit, 1976: 17). Gendhing Dhenggung Asmarandana termasuk kelompok gendhing ageng, karena berbentuk Kethuk 4 Kerep minggah 8 . Struktur yang terdapat pada Gendhing Dhenggung Asmarandana terdiri dari: buka, merong, umpak inggah, dan inggah. Pada umumnya gendhing-gendhing bonang yang berlaras pelog baik pelog barang maupun pelog lima sebelum buka didahului dengan lagu yang disebut adangiyah. 
Adapun balungan Gendhing Dhenggung Asmarandana, kethuk 4 kerep minggah 8 laras pelog pathet lima.

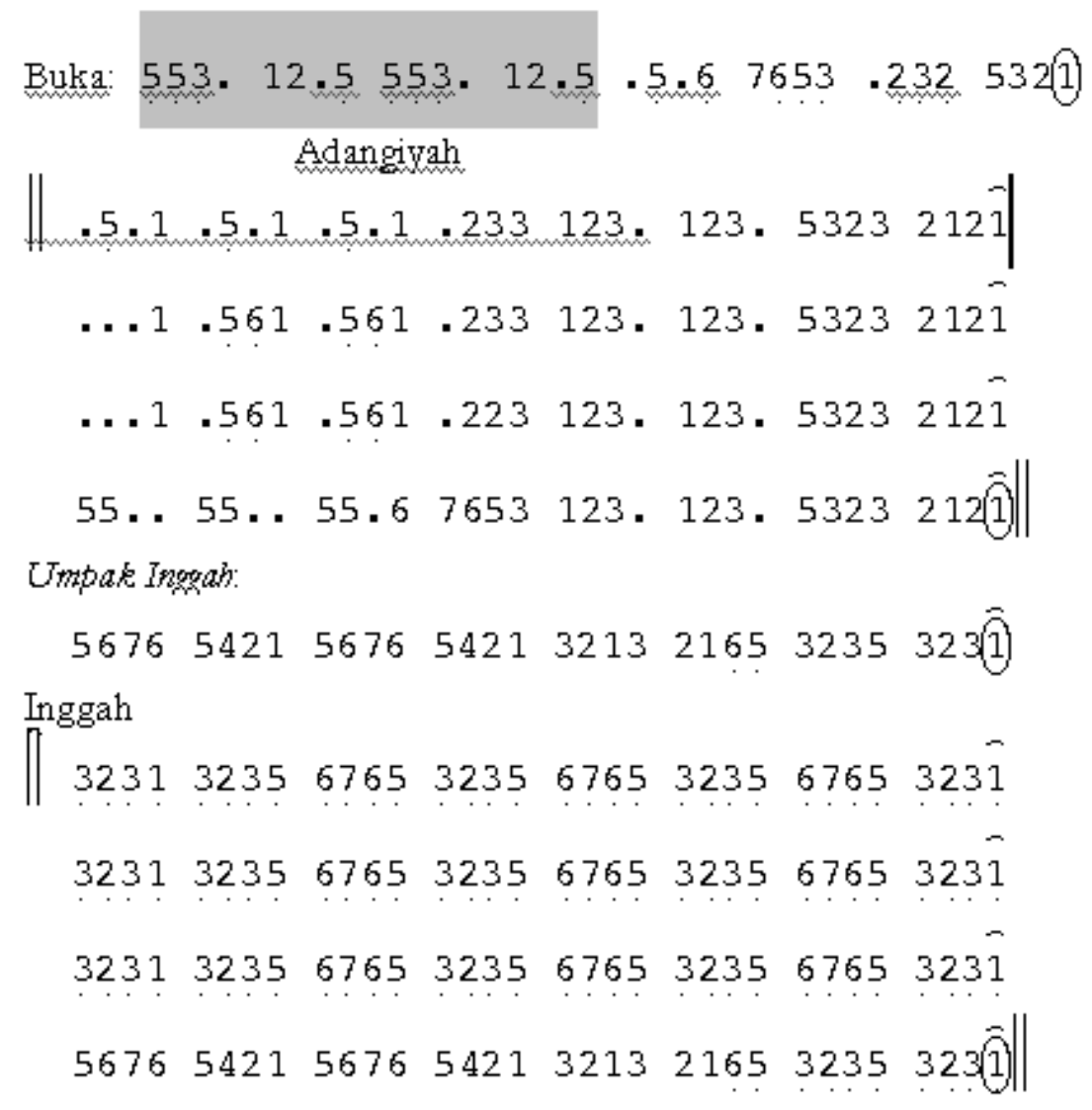

\section{B. Gendhing Dhegung Banten}

Pada tradisi Karawitan Gaya Yogyakarta dikenal istilah gendhing lirihan dan gendhing soran. Untuk gendhing lirihan tidak akan dibahas dalam tulisan ini. Sedang yang dimaksud soran adalah sajian gendhing yang ditabuh dengan volume "sora" atau keras, sehingga akan terkesan rasa gagah, tegas dan agung. Penyajian gendhing soran tidak melibatkan ricikan garap seperti gendhing bonang karawitan Gaya Surakarta. Menurut Bambang Sri Atmaja yang dikutip oleh Muclas Hidayat menyebutkan bahwa:

"Dahulu pada masa pemerintahan Sri Sultan Hamengku Buwono VIII melakukan kunjungan ke kraton Kesultanan Banten, kemudian dijamu sebuah permainan Dhegung. Setelah kembali ke Yogyakarta, Sultan Hamengku Buwono VIII, membuat gendhing yang diberi nama Dhegung Banten karena terispirasi permainan gamelan dhegung yang ada di kraton Banten (Hidayat, 2008: 160).
Dari pernyataan di atas dapat diketahui bahwa gendhing Dhegung Banten diciptakan oleh Sri Sultan Hamengku Buwono VIII. Sumarsam (2003:68) dalam bukunya yang berjudul Gamelan, Interaksi Budaya dan Perkembangan Musikal di Jawa menyebutkan bahwa Sultan Hamengku Buwono VIII memerintah pada tahun 19211939. Sang Maestro karawitan dari Yogyakarta KPH. Notoprojo (2000), atau yang lebih populer dengan sebutan Pak Cakra, menyatakan bahwa pada masa pemerintahan Sultan Hamengku Buwono VIII, di Kraton Yogyakarta mempunyai abdi dalem niyogo yang sangat handal tidak hanya piawai memainkan ricikan gamelan (rebab, kendhang, gender), tetapi juga sangat "mumpuni" dalam hal membuat gendhing. Abdi dalem itu ialah RW. Laras Sumbogo lebih lanjut dijelaskan bahwa RW Laras Sumbogo dahulu belajar menabuh gamelan dengan empu- empu karawitan di Solo dan kemudian beliau beristri dari Solo. Gendhing- gendhing karya RW. Laras Sumbogo 
bernuansa "Ngayojan" antara lain: Ngeksi-ganda, Ngeksibrata, Ngeksi Laras, Ngeksingestuti, Ngeksiminulya, Madyaratri, Suryaratri, Sariratri, Madutama, Maduganda, Candrakusuma, Candraririh dan yang lainnya.

Gendhing Dhegung Banten pada tradisi karawitan gaya Yogyakarta tergolong jenis gending soran (Muclas Hidayat, 2008: 6). Gendhing Soran biasanya disajikan pada bagian awal penyajian uyon-uyon, baik uyon-uyon siang maupun uyonuyon malam Istilah uyon-uyon sama dengan istilah klenengan karawitan gaya Surakarta baik uyon-uyon maupun klenengan mempunyai pengertian sajian karawitan mandiri, jadi bukan sajian karawitan untuk mengiringi tari, pakeliran dan seni tradisi lainnya.

Gendhing tradisi karawitan gaya Yogyakarta pada dasarnya dikelompokkan menjadi tiga yaitu: Gendheng Gedhe (ageng) yaitu gendhing dengan kethuk 4 atau lebih; Gendhing tengahan yang mempunyai kethuk 2 ndawah kethuk 4; Gendhing alit gendhing yang mempunyai kethuk 2 ndawah kethuk 2 (Wulan Karahinan, tt: 12). Berdasarkan pengelompokkan gendhing tersebut, maka Gendhing Dhegung Banten termasuk kelompok gendhing ageng, karena setiap satu tabuhan kenong terdapat 4 tabuhan kethuk berjarak dekat (Surakarta disebut kethuk 4 kerep), dan karena berlaras pelog maka gendhing Dhegung Banten menggunakan pola Kendangan Semang Alit.

Gendhing Dhegung Banten terdiri dari: (1) Buka (sebelum buka di awali dengan umpak buka, istilah umpak buka sama dengan istilah adangiyah pada karawitan gaya Surakarta); (2) Lamba dan Dados; (3) Pangkat Ndawah: (4) Dhawah; dan (5) Suwukan (suatu lagu yang disajikan hanya khusus untuk suwuk). Adapun balungan Gendhing Dhegung Banten kethuk 4 kerep minggah 8 laras pelog pathet lima, kendangan semang sebagai berikut.

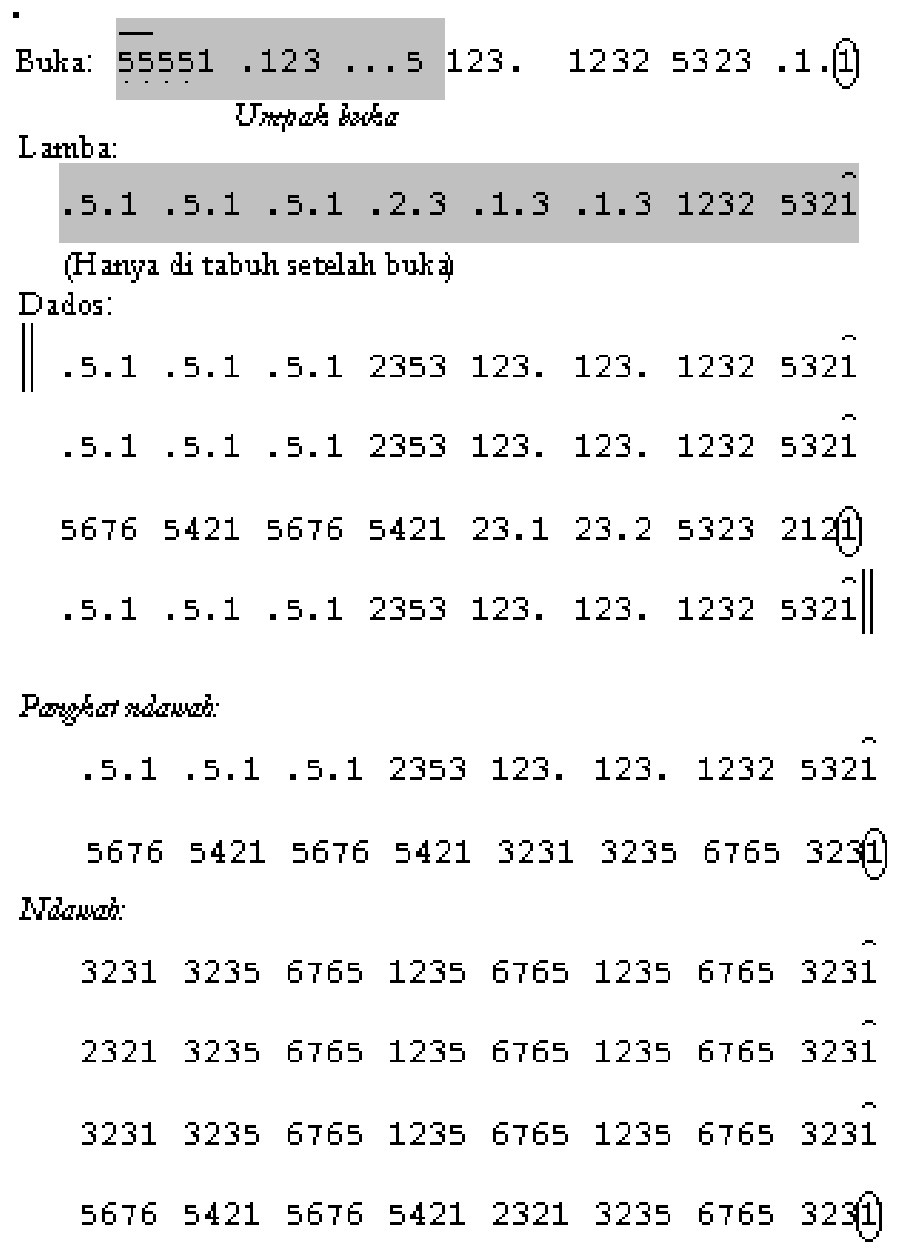




\section{Analisis Balungan}

Dalam dunia karawitan setidak-tidaknya dikenal dua pengertian tentang balungan, yakni balungan sebagai kerangka gendhing dan balungan yang berarti kelompok ricikan atau instrumen yang terdiri dari demung, saron barung, saron penerus dan slenthem. Pengertian balungan dalam tulisan ini adalah balungan sebagai kerangka gendhing.

Untuk mengetahui persamaan dan perbedaan balungan antara gendhing Dhenggung Asmara-

Buka:

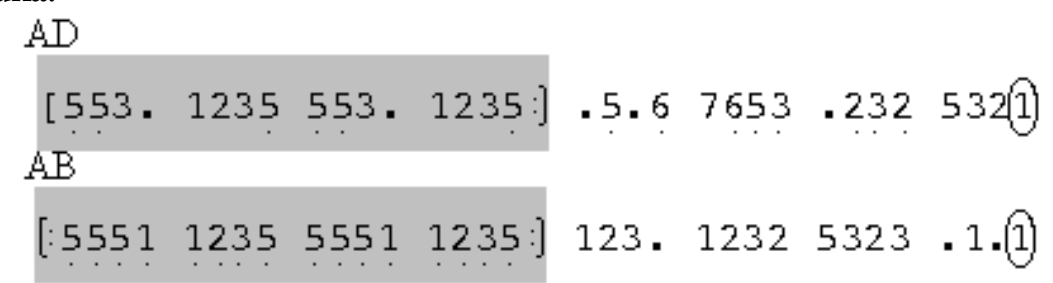

Analisa bagian Buka:

Nada yang diberi kurung, karawitan tradisi Surakarta atau AD disebut Adangiyah, sedangkan tradisi karawitan Yogyakarta atau $\mathrm{AB}$ disebut Umpak Buka, dan pada seleh nada $\mathrm{t}$ (ma) dibarengi tabuhan seluruh ricikan balungan.

Merong (AD) / Lamba-dados (AB)

\begin{tabular}{|c|c|c|c|c|c|c|c|c|}
\hline Kode & 1 & 2 & 3 & 4 & 5 & 6 & 7 & 8 \\
\hline $\mathrm{AD}$ & .5 .1 & .5 .1 & .5 .1 & .233 & 123. & 123. & 5323 & 2121 \\
\hline $\mathrm{AB}$ & .5 .1 & .5 .1 & .5 .1 & .2 .3 & .1 .3 & .1 .3 & 1232 & 5321 \\
\hline $\mathrm{AD}$ &. .1 & .561 & .561 & .233 & 123. & 123. & 5323 & 2121 \\
\hline $\mathrm{AB}$ & .5 .1 & .5 .1 & .5 .1 & 2353 & 123. & 123. & 1232 & 5321 \\
\hline $\mathrm{AD}$ &. .1 & .561 & .561 & .233 & 123. & 123. & 5323 & 2121 \\
\hline $\mathrm{AB}$ & .5 .1 & .5 .1 & .5 .1 & 2353 & 123. & 123. & 1232 & 5321 \\
\hline $\mathrm{AD}$ & $55 .$. & $5 .$. & 55.6 & 7653 & 123. & 123. & 5323 & $212(1)$ \\
\hline $\mathrm{AB}$ & 5676 & 5421 & 5676 & 5421 & 23.1 & 23.2 & 5323 & $212(1)$ \\
\hline
\end{tabular}


Analisa balungan:

- Kenong pertama: gatra ke 1, 2, dan 3 sama; gatra ke 4 berbeda, gatra ke 5 dan 6 sama; gatra ke 7 dan 8 berbeda.

- Kenong kedua: gatra ke 1, 2, dan 3 sama; gatra ke 4 berbeda, gatra ke 5 dan 6 sama; gatra ke 7 dan 8 berbeda.

- Kenong ketiga: gatra ke 1, 2, dan 3 sama; gatra ke 4 berbeda, gatra ke 5 dan 6 sama; gatra ke 7 dan 8 berbeda.

- Kenong keempat: gatra ke 1, 2, 3, 4, 5 dan 6 berbeda; gatra ke 7 dan 8 sama.
Kenong pertama, kedua dan ketiga; gatra 1 , 2, 3, dan 4 sekalipun berbeda namun seleh gatranya sama, gatra ke 7 berbeda karena $\mathrm{AD}$ seleh gatranya 3 (lu) sedang $\mathrm{AB}$ seleh gatranya 2 (ro). Gatra yang ke 8 selehnya sama yaitu seleh 1 (ji). Kenong keempat AD gatra ke 1 sampai dengan gatra ke 6 baik susunan melodi maupun seleh gatra berbeda jauh, untuk $A B$ gatra 1 sampai gatra ke 4 adalah susunan melodi balungan bagian Ndawah.

Umpak Inggah (AD)/ Pangkat Ndawah (AB)

\begin{tabular}{|c|c|c|c|c|c|c|c|c|}
\hline Kode & 1 & 2 & 3 & 4 & 5 & 6 & 7 & 8 \\
\hline $\mathrm{AD}$ & 5676 & 5421 & 5676 & 5421 & 3213 & 2165 & 3235 & $323(1)$ \\
\hline $\mathrm{AB}$ & 5676 & 5421 & 5676 & 5421 & 3231 & 3235 & 6765 & 323 \\
\hline
\end{tabular}

Analisa balungan:

- Gatra ke 1,2, 3, 4 dan gatra ke 8 sama, gatra 5, 6, dan 7 berbeda, untuk gatra ke 6 dan 7 seleh gatranya sama dan gatra ke 5 berbeda yakni: $\mathrm{AD}$ seleh 3 (lu) dan $\mathrm{AB}$ seleh 1 (ji).

Inggah $(\mathrm{AD}) / \mathrm{Ndawah}(\mathrm{AB})$

\begin{tabular}{|c|c|c|c|c|c|c|c|c|}
\hline Kode & 1 & 2 & 3 & 4 & 5 & 6 & 7 & 8 \\
\hline $\mathrm{AD}$ & 3231 & 3235 & 6765 & 3235 & 6765 & 3235 & 6765 & 3231 \\
\hline $\mathrm{AB}$ & 3231 & 3235 & 6765 & 1235 & 6765 & 1235 & 6765 & 3231 \\
\hline $\mathrm{AD}$ & 3231 & 3235 & 6765 & 3235 & 6765 & 3235 & 6765 & 3231 \\
\hline $\mathrm{AB}$ & 3231 & 3235 & 6765 & 1235 & 6765 & 1235 & 6765 & 3231 \\
\hline $\mathrm{AD}$ & 3231 & 3235 & 6765 & 3235 & 6765 & 3235 & 6765 & 3231 \\
\hline $\mathrm{AB}$ & 3231 & 3235 & 6765 & 1235 & 6765 & 1235 & 6765 & 3231 \\
\hline $\mathrm{AD}$ & 5676 & 5421 & 5676 & 5421 & 3213 & 2165 & 3235 & $323(1)$ \\
\hline $\mathrm{AB}$ & 5676 & 5421 & 5676 & 5421 & 3231 & 3235 & 6765 & $323(1)$ \\
\hline
\end{tabular}


Analisa balungan:

- Kenong pertama gatra ke 1, 2, 3, 5, 7 dan 8 adalah sama; gatra ke 4 berbeda $\mathrm{AD}$ seleh 3 (lu) dan $A B$ seleh 1 (ji); gatra ke 6 berbeda pada slah balungan ke 3 yaitu AD 6 (nem) dan $\mathrm{AB}$ slah balungan ke 3 adalah 3 (lu).

- Kenong kedua dan kenong ketiga sama persis dengan kenong pertama

- Kenong keempat Gatra ke 1, 2, 3, 4 dan gatra ke 8 sama, gatra 5, 6, dan 7 berbeda, untuk gatra ke 6 dan 7 seleh gatranya sama dan gatra ke 5 berbeda yakni: $A D$ seleh 3 (lu) dan $A B$ seleh 1 (ji).
Suwukan

Gendhing Dhenggung Asmarandana tidak mempunyai lagu atau cengkok yang disajikan untuk suwuk, sedangan gendhing Dhegung Banten mempunyai lagu atau cengkok yang khusus disajikan bilamana gendhing suwuk. Lagu atau cengkok tersebut lazim di sebut suwukan. Setelah dilakukan penelitian ternyata suwukan yang ada pada gendhing Dhegug Banten itu mempunyai kesamaan dengan suwukan yang terdapat pada gendhing Gonjang Anom Kethuk 8 Kerep Minggah 16 Laras Pelog Pathet Nem. Menurut buku Wedhapradangga Gendhing Gonjang Anom adalah gendhing gaya Surakarta dicipta pada masa pemerintahan Pakoe Boewana IV. Adapun suwukan gendhing Gonjang Anom seperti di bawah ini:

\begin{tabular}{|l|c|c|c|c|c|c|c|c|}
\hline Kode & 1 & 2 & 3 & 4 & 5 & 6 & 7 & 8 \\
\hline Suwh Gendhing Gonjang Anom \\
\hline AD & 61.6 & 2165 & 61.6 & 2165 & .54 & 24.2 & 4254 & 2165 \\
\hline
\end{tabular}

Analisa Balungan:

- Gatra ke 1, 2, 4, 5, 6, dan 8 adalah sama, gatra ke 3 berbeda yakni $A D$ seleh 6 (nem) dan $A B$ seleh 2 (ro), Gatra ke 7 berbeda yakni AD seleh 4 (pat) dan $A B$ seleh 5 (ma). Dengan demikian

\section{Tafsir Garap Bonang Barung}

Garap dalam karawitan tradisi gaya Yogyakarta dan Surakara secara ringkas dapat dimaknai kreativitas pengrawit dalam mewujudkan gendhing atau balungan gending ke dalam bentuk permainan ricikan gamelan untuk mencapai suatu kualitas sajian. Supanggah (2002: 224) menyatakan bahwa, garap pada dasarnya adalah suatu tindakan yang menyangkut imajinasi, interpretasi, dan kreativitas. Garap dalam karawitan merupakan faktor terpenting dalam menentukan kualitas hasil sajian.

Perlu diketahui bahwa gendhing-gendhing tradisi hanyalah berujud kerangka atau balungan gendhing saja. Supaya menjadi sajian yang enak perbedaan yang terdapat pada suwukan yang mencolok adalah pada seleh gatra ke 3 dan ke 7.

dinikmati, maka balungan gendhing itu harus ditafsir atau diinterpretasi garapnya, sehingga kualitas sajian suatu gendhing sangat tergantung pada kemampuan, pengalaman dan tafsir garap oleh yang menggarapnya. Balungan gendhing yang tersusun pada gatra-gatra merupakan bahan mentah yang harus diolah, dimasak dan dibumbui oleh ricikan garap (termasuk ricikan bonang barung), sehingga menjadi sajian yang dapat dinikmati.

Ricikan Bonang Barung adalah salah satu ricikan garap terutama untuk gendhing-gendhing bonang (Surakarta) dan gendhing-gendhing soran (Yogyakarta). Seorang penabuh bonang barung harus dapat menafsir balungan gendhing 
dengan mempertimbangkan pathet (terutama teknik imbal), irama dan laya. Beberapa teknik tabuhan bonang barung yang digunakan untuk menggarap sebuah gendhing diantaranya adalah mbalung, gembyang, mipil lamba, mipil rangkep, imbal dan jika ada klenangan. Berkaitan dengan judul tulisan ini teknik tabuhan bonang barung

\section{Mbalung}

Teknik tabuhan mbalung digunakan untuk buka dan dua gatra setelah gong buka (Surakarta), sedangkan di Yogyakarta mbalung hanya digunakan untuk buka saja.

Contoh buka:

1) Buka Dhenggung Asmarandana

$$
553 \cdot 12.5 \quad 553 \cdot 12.5 \cdot 5 \cdot 6 \quad 7653 \cdot 232 \quad 5321
$$

2) Buka Dhegung Banten

$$
\begin{array}{llllll}
55551 & 1235 & \overline{5} 5551 & 1235 & 123.1232 & 5323.1 .(1)
\end{array}
$$

Gembyang

Teknik tabuhan gembyang pada dasarnya untuk menggarap balungan kembar

1) Teknik Gembyang:

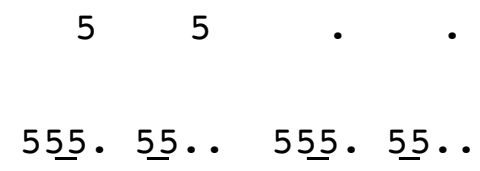

2) Pada gendhing Dhegung Banten ditemukan istilah gembyang midak, yaitu digunakan untuk menggarap susunan balungan setelah gong buka sampai enam gatra menjelang kenong ke pertama, contoh:

$\begin{array}{cccccccc}\cdot & 5 & . & 1 & . & 5 & . & 1 \\ 5 & 5 & 1 & 1 & 5 & 5 & 1 & 1\end{array}$

Mipil Lamba

Teknik ini digunakan pada irama tanggung, contohnya:

1) Balungan : $\quad 1 \quad 2 \quad 3 \quad 2$

Bonangan: $\quad \begin{array}{llllllll}1 & 2 & 1 & 2 & 3 & 2 & 3 & 2\end{array}$

2) Balungan : $\begin{array}{lllll}3 & 2 & 3 & 1\end{array}$

Bonangan: $\quad 32 \quad 325$.

(Mipil lamba pada Dhegung Banten) 


\section{Mipil Rangkep}

Teknik pada gendhing Dhenggung Asmarandana maupun Dhegung Banten

1) Mipil Rangkep Dhenggung Asmarandana

$\begin{array}{lllll}\text { Balungan : } & 1 & 2 & 3 & 2\end{array}$

Bonangan: 121..21 . 323. .23.

2) Mipil rangkep pada gendhing Dhegun Banten
Balungan :
$\begin{array}{lllll}3 & 2 & 3 & 1\end{array}$

Bonangan: $\quad 323.3232313 .3131$

Di dalam tulisan Muchlas Hidayat (2008: tabuhan nglagu dhegungan disajikan pada irama 70) disebutkan bahwa pada gendhing Dhegung dados yaitu untuk menggarap balungan sebagai Banten ada bonangan yang spesifik yang lazim disebut bonangan nglagu dhegungan. Teknik

berikut:
1) Balungan :
5
1
Bonangan:
$.512 \quad 3535 \overline{.5} 653 \quad \overline{.2} 121$
2) Balungan :
53
2
1
Bonangan:
535. $5353 \quad \overline{.2} 153 \quad \overline{.2} 121$
3) Balungan :
21
2
1
Bonangan:
$\overline{.2} 153 \quad \overline{2} 153.2153 \quad \overline{2} 121$

Dari analisa garap bonang barung dapat diketahui gendhing Dhegung Banten kethuk 4 kerep ndhawah 8 laras pelog pathet lima kendhangan semangalit, terdapat garap tabuhan bonang barung mirip dengan garap tabuhan bonang sunda (Jawa Barat). Garapan yang dimaksud diketemukan pada bagian Lamba dan Dados kenong ke satu, dua dan tiga pada gatra ke satu, dua, tiga dan ke delapan, serta terdapat pada kenong ke empat gatra ke delapan bersamaan dengan tabuhan gong. Garap seperti itu tidak terdapat pada tabuhan bonang barung gendhing Dhenggung Asmardana pada khususnya dan gendhing-gendhing karawitan gaya Surakarta pada umumnya. 


\section{Rekapitulasi Komparasi Gendhing \\ Dhenggung Asmaradana dan Gendhing Dhegung Banten.}

\begin{tabular}{|c|c|c|c|}
\hline No & $\begin{array}{c}\text { Unsur } \\
\text { Pembanding } \\
\end{array}$ & $\begin{array}{c}\text { Dhenggung Asmaradana } \\
\text { Surakarta }\end{array}$ & $\begin{array}{c}\text { Dhegung Banten } \\
\text { Yogyakarta } \\
\end{array}$ \\
\hline 1. & Yasan & $\begin{array}{l}\text { Sinuhun Paku Buwono IV } \\
(1788-1820)\end{array}$ & $\begin{array}{l}\text { Ciptaan Sultan Hamengku } \\
\text { Buwono VIII } \\
\text { (1921- 1939) }\end{array}$ \\
\hline 2 . & Gendhing & Kethuk 4 kerep minggah 8 & $\begin{array}{l}\text { Kethuk } 4 \text { kerep minggah } 8 \\
\text { ( kendangan semang) }\end{array}$ \\
\hline 3. & Laras & Pelog & Pelog \\
\hline 4. & Pathet & Lima & Lima \\
\hline 5. & $\begin{array}{l}\text { Struktur } \\
\text { gendhing }\end{array}$ & $\begin{array}{l}\text { 1. Adangiyah- buka } \\
\text { 2. Merong } \\
\text { 3. Umpak inggah } \\
\text { 4. Inggah } \\
\text { 5. - }\end{array}$ & $\begin{array}{l}\text { 1. Umpak buka- buka } \\
\text { 2. Lamba- dados } \\
\text { 3. pangkah- nDawah } \\
\text { 4. nDawah } \\
\text { 5. Suwukan }\end{array}$ \\
\hline
\end{tabular}

Berdasarkan analisis dapat diketahui bahwa meskipun kedua gendhing di atas berbeda namanya, tetapi setelah diadakan penelitian ternyata mempunyai kemiripan hampir 95\%. Kemiripan kedua gendhing itu meliputi; laras, patet, bentuk, struktur dan beberapa balungan gending. Gendhing Dhenggung Asmaradana berlaras pelog berpatet lima berbentuk gendhing ketuk 4 kerep minggah 8 laras pelog patet lima dan berstruktur; buka, merong, umpak inggah dan inggah serta merupakan gendhing bonang. Sedangkan gendhing Dhegung Banten berlaras pelog berpatet lima, berbentuk gendhing ketuk 4 kerep ndawah 8 laras pelog patet lima kendhangan semang berstruktur buka, lamba, dados, pangkat ndawah dan ndawah serta terdapat lagu atau cengkok suwukan gendhing ini adalah gendhing soran.

Kemiripan yang terdapat pada kedua gendhing tersebut meliputi; laras, patet, bentuk, struktur dan beberapa balungan gendhing. Penulis menduga bahwa seniman atau pengrawit atau komposer yang membuat gendhing Dhegung Banten setidaknya pernah mendengar dan atau melihat balungan gendhing, laras, patet, bentuk dan struktur gendhing. Hal ini berdasarkan pada historis gendhing bahwa gendhing Dhenggung Asmarandana dicipta lebih dahulu daripada gendhing Dhegung Banten, karena gendhing Dhenggung Asmarandanadicipta pada masa pemerintahan Pakoe Boewono IV 1788 -1820 dan gendhing Dhegung Banten baru dicipta pada jaman pemerintahan Sultan Hamengku Buwana VIII 1921 -1939. Perbedaan dari kedua gendhing tersebut hanya terdapat pada garap tabuhan bonang barung yaitu pada kenong ke 1, 2, dan 3, Gatra ke 1, 2, 3, dan 8, serta pada kenong ke empat gatra ke 8 .

\section{Penutup}

Keraton Kasunanan Surakarta dan Keraton Kasultanan Yogyakarta dahulu bersumber dari Keraton Mataram. Oleh sebab itu, budaya yang berada di keraton tersebut mempunyai banyak kemiripan termasuk gendhing-gendhing karawitan. Kemiripan itu salah satu contohnya yaitu Gendhing Dhenggung Asmaradana gendhing kethuk 4 kerep minggah 8 laras pelog patet lima dan Gendhing Dhegung Banten gendhing kethuk 4 kerep ndawah 8 laras pelog patet lima kendhangan Semang. Persamaan keduanya terletak pada laras, pathet, bentuk gendhing, struktur gendhing, serta sekitar 95\% balungannya sama. Sedangkan perbedaannya hanya pada nama dan garap tabuhan bonang.

\section{Kepustakaan}

Hidayat, Muclas. 2008. "Penyajian Gendhinggendhing Tradisi Dhegung Banten, Candra Ririh, Pandhelori, dan Rina-rina”. Tugas Akhir S-1 Karawitan, Fakultas Seni Pertunjukan ISI Yogyakarta. 
Karahinan, Raden Bekel Wulan. 1998. Gendhing - gendhing Mataram gaya Yogyakarta dan cara menabuh Jilid I. Yogyakarta: K.H.P. Krida Mardawa karaton Ngayogyakarta Hadiningrat.

Martopangrawit. 1976. Pengetahuan Karawitan I. Surakarta: Akademi Seni Karawitan Indonesia Surakarta.

Mlayawidada. 1977. Gendhing-gendhing Jawa Gaya Surakarta., Jilid I, II, III. Surakarta: Akademi Seni Karawitan Indonesia.

Praja Pangrawit, R.Ng. 1990. Wedhapradangga: Serat Sujarah Riwayating Gamelan (Serat Saking Gotek. Surakarta: STSI Press.

Sedyawati. Edi, 1981. Pertumbuhan Seni Pertunjukan. Jakarta: Sinar Harapan.

Soedarsono., "Beberapa Catatan Tentang Seni Pertunjukan Indonesia”, Makalah Ceramah., Konservatori Tari Indonesia., Yogyakarta., tt.
Sumarsam. 2003. Gamelan: Interaksi Budaya dan Perkembangan Musikal di Jawa. Yogyakarta: Pustaka Pelajar.

Supanggah, Rahayu. 1988. "Gatra Inti dari Kerep Gendhing Tradisi Jawa "., dalam Wiled Volume II No: 30. . 2002. Bothekan Karawitan I. Jakarta: Masyarakat Seni Pertunjukan Indonesia (MSPI).

\section{Informan}

KPH. Notoprojo (92 th). Taman Siswa Yogyakarta. Jumadi Broto Puspito (67 th), Pengrawit, Surakarta

KRA Saptodiningrat (58 th), Pengrawit, Surakarta

KRT Surosodiningrat (69 th), Pengrawit, Surakarta. 